\title{
Schmallenberg virus antibody persistence in adult cattle after natural infection and decay of maternal antibodies in calves
}

\author{
Armin RW Elbers ${ }^{1 *}$, Norbert Stockhofe-Zurwieden ${ }^{2}$ and Wim HM van der Poel ${ }^{3}$
}

\begin{abstract}
Background: Schmallenberg virus (SBV) has swept through the major part of Europe in the period 2011-2013. A vaccine against SBV has been developed and may be a possible preventive instrument against infection. Presently, there is no data available to refute the assumption that natural SBV infection results in long-term immunity. In that respect, it is of interest to know how long (protecting) virus-neutralizing antibodies are present in naturally infected animals. New-born calves acquire passive immunity from their dams by ingestion and absorption of antibodies present in colostrum, which can block the production of serum antibodies when vaccine is administered to calves with maternally derived antibodies. In that respect, it is useful to know how long it takes for maternal antibodies against SBV to disappear in young animals born from infected dams.
\end{abstract}

Results: Longitudinal whole-herd serological monitoring using virus neutralization test (VNT) indicated that $80 \%$ of adult dairy cows still had measurable antibodies against SBV at least 24 months after the estimated introduction of the virus into the herd. Median ${ }^{2}$ Log VNT titer of the adult dairy cows ( $\geq 1$ year) dropped from 8.6 to 5.6 in a period of 17 months. Median ${ }^{2}$ Log VNT maternal antibodies titers of calves sampled within 30 days after birth was 8 . Calves lost their maternally-derived antibodies after 5-6 months. There was a definite positive relationship between the VNT titer of the dam and the VNT titer of the corresponding calf (age $\leq 30$ days) of dam-calf combinations sampled on the same day: the higher the VNT titer of the dam, the higher the VNT titer (maternal antibodies) of the calf.

Conclusions: Our field data support the assumption that natural SBV infection in adult cows results in persistence of specific antibodies for at least two years. Based on the observed decay of maternally-derived antibodies in calves, it is presumed safe to vaccinate calves against SBV at an age of approximately 6 months.

Keywords: Schmallenberg virus, Cattle, Dairy cows, Immunity, Maternal antibodies, Virus-neutralizing antibodies

\section{Background}

Schmallenberg virus (SBV), a novel Orthobunyavirus, has swept through the major part of Europe in the period 2011-2013, reaching as far North as Finland, Turkey in the East, and Spain in the South [1,2]. A serological survey of blood samples, collected in the period November 2011 - January 2012, from a representative sample of cattle in the Netherlands indicated a high seroprevalence of antibodies against SBV [3]. So far, the impression is that the clinical impact of the disease on

\footnotetext{
* Correspondence: armin.elbers@wur.nl

'Department of Epidemiology, Crisis organisation and Diagnostics, Central Veterinary Institute, part of Wageningen UR, PO Box 65, NL-8200AB Lelystad, Netherlands

Full list of author information is available at the end of the article
}

ruminant livestock is limited [1]. A vaccine against SBV has been developed [4] and may be a possible preventive instrument against infection. Presently, there is no data available to refute the assumption that natural SBV infection results in long-term immunity [1], as was seen earlier with natural infection of cattle with bluetongue virus serotype 8 [5]. In that respect, it is of interest to know how long (protecting) virus-neutralizing antibodies are present in naturally infected animals. Newborn calves acquire passive immunity from their dams by ingestion and absorption of antibodies present in colostrum. The estimated duration and benefit of this passively derived humoral immunity can vary greatly depending on the 
Table 1 Distribution of cows with a ${ }^{2}$ Log virus neutralization test titer $\geq 3$ by sampling date and age category

\begin{tabular}{llllll}
\hline $\begin{array}{l}\text { Sampling } \\
\text { date }\end{array}$ & $\begin{array}{l}\text { Total number } \\
\text { of cows }\end{array}$ & $\begin{array}{l}\text { Number of } \\
\text { cows } \geq \mathbf{1} \text { year }\end{array}$ & $\begin{array}{l}\text { Number of cows } \geq \mathbf{1 y e a r} \\
\text { with }{ }^{2} \text { Log VNT titer } \geq \mathbf{3}\end{array}$ & $\begin{array}{l}\text { Number of } \\
\text { cows }<\mathbf{1} \text { year }\end{array}$ & $\begin{array}{l}\text { Number of cows }<1 \text { year } \\
\text { with } \mathbf{2}^{2} \text { Log VNT titer } \geq \mathbf{3}\end{array}$ \\
\hline 19 Apr 2012 & 108 & 87 & $87(100 \%)$ & 21 & $17(81 \%)$ \\
17 Sept 2012 & 108 & 89 & $89(100 \%)$ & 19 & $19(100 \%)$ \\
9 Dec 2012 & 110 & 89 & $88(99 \%)$ & 21 & $16(76 \%)$ \\
23 Apr 2013 & 116 & 86 & $84(98 \%)$ & 30 & $15(50 \%)$ \\
23 Sept 2013 & 109 & 87 & $70(80 \%)$ & 22 & $2(9 \%)$ \\
\hline
\end{tabular}

colostrum production (quantity and quality) and the quantity of antibody ingested and absorbed [6]. Passive immunity can block the production of serum antibodies when vaccine is administered to calves with maternally-derived antibodies [7]. In that respect, it is useful to know how long it takes for maternal antibodies against SBV to disappear in young animals born from infected dams. To examine the development and the course of neutralizingantibodies against SBV over time, in a dairy herd in the eastern part of the Netherlands where SBV RNA was detected in a high proportion of Culicoides caught in the autumn of 2011 [8], all animals were blood-sampled five times in a 17-month period, and tested for SBV specific neutralizing antibodies.

\section{Results and discussion}

At the 1st sampling (19 April 2012), all adult cows ( $\geq 1$ year of age) tested seropositive, only four calves (6 months of age) tested seronegative. Seventeen months later at the fifth sampling (23 September 2013), 80\% of the adult cows still tested seropositive, while only $9 \%$ of the cows $<1$ year of age tested seropositive (Table 1). Median ${ }^{2} \log$ VNT titer of the adult cows dropped from 8.6 (range: 5.5 - 9.5) to 5.6 (range: $2-8$ ) in a period of 17 months (Figure 1). It can be assumed that the adult cows became infected around the time that SBV RNA was detected for the first time in Culicoides biting midges caught at this dairy farm on 14 September 2011 [8]. This means that at least 24 months after natural infection, animals most likely were protected against re-infection.

Eleven heifers seroconverted (seronegative in April 2012 and high VNT-titers $\left({ }^{2} \log\right.$ VNT titer $\left.\geq 6\right)$ in September 2012) and one dairy cow seroconverted between the September and December 2012 samplings. The low rate of seroconversions matched with a significantly lower (six times) proportion of SBV-infected Culicoides observed in

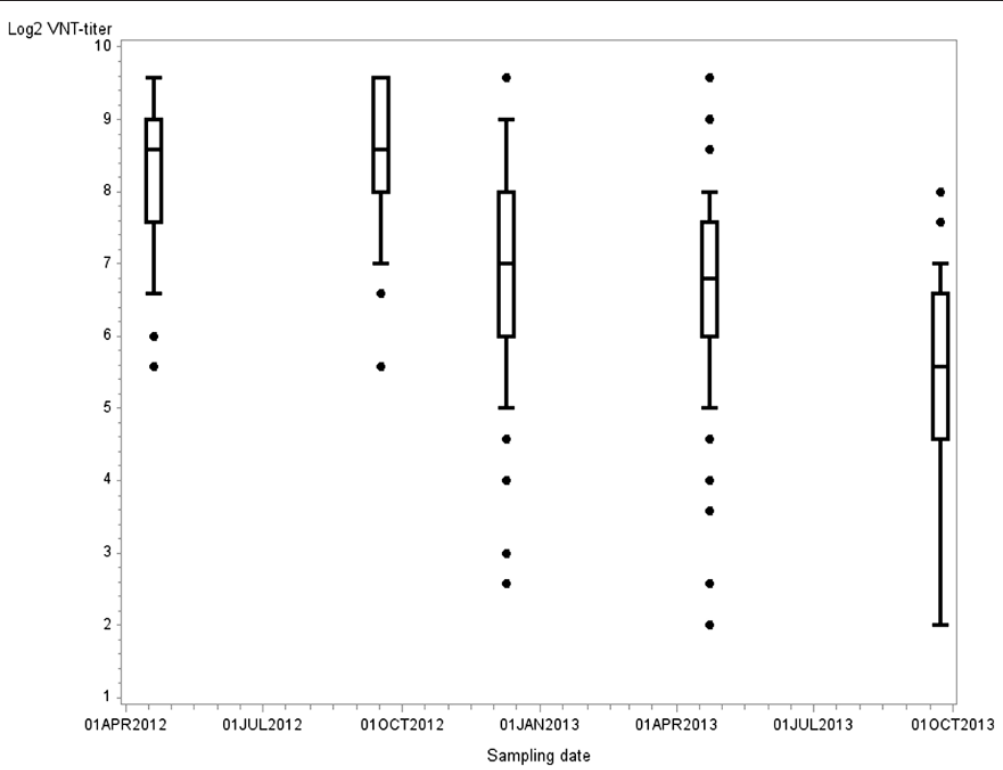

Figure 1 Distribution of virus neutralization test (VNT) antibody titers ( ${ }^{2}$ Log-scale) against Schmallenberg virus in dairy cattle $\geq 1$ year of age by date of sampling, summarized by a box and whisker plot (the central line in the box plot indicates the median of the data, while the edges of the box indicate the 25th and 75th percentiles; extending from the box are whiskers, the top whisker expands to the 90th percentile and the bottom whisker to the 10th percentile; beyond the whiskers are observations that are relatively far from the median). 


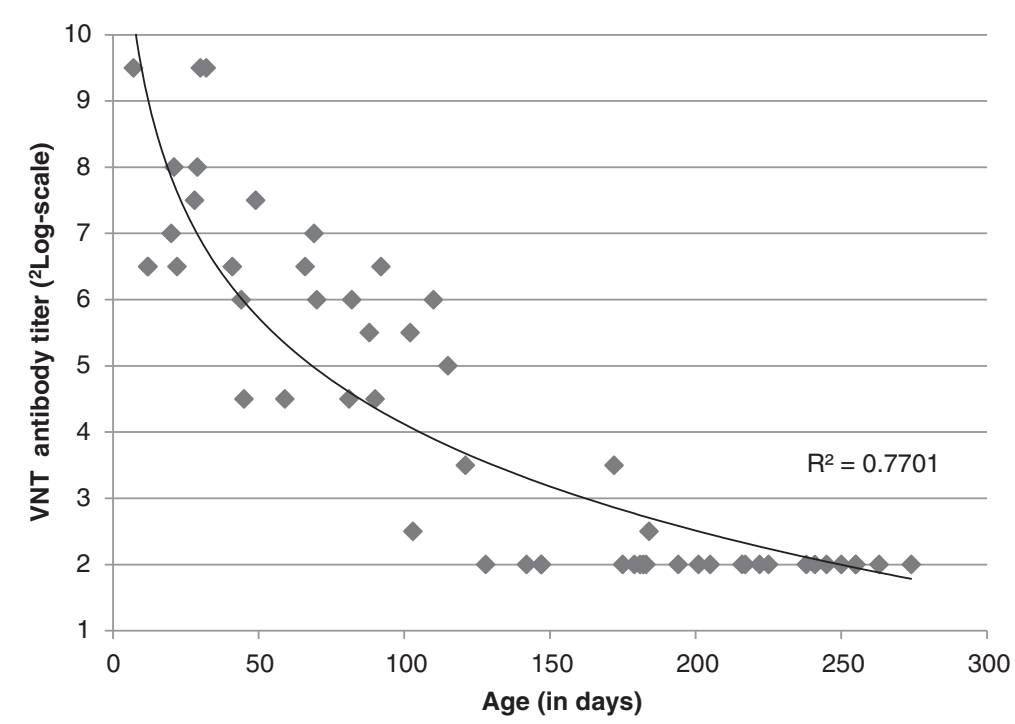

Figure 2 Virus neutralization test (VNT) antibody titers against Schmallenberg virus of 25 calves by age at sampling (based on 2-3 samplings per calf).

2012 compared to 2011 [9], and it can be assumed that there was a much lower level of SBV-circulation in the area in 2012 compared to 2011.

Calves that were bled $\leq 30$ days after birth had a median ${ }^{2} \log$ VNT titer of 8 (range: 6.5 - 9.5) and became seronegative $\left({ }^{2} \log\right.$ VNT titer < 3) within 5-6 months (Figure 2). The presence of maternally-derived antibodies may hamper the effective response to vaccination. Therefore, it is important to consider the age at which the calves lose their maternal antibody, previous to starting a vaccination campaign. There are sparse reports on the course of decay of maternal antibodies against Orthobunyaviruses in ruminants. Tsutsui et al. [10] showed that dairy calves lost their maternally derived antibodies against Akabane virus at an age of approximately 4 months, while Grimstad et al. [11] showed that young white-tailed deer lost their maternal antibodies against Jamestown Canyon virus at an age of 5-6 months. Our results seem to be in range with the abovementioned studies. To achieve an effective response to vaccination it can be advised to vaccinate calves at an age of at least 6 months.

There was a definite positive relationship (correlation coefficient: 0.73 , significance level: $<0.01$ ) between the VNT titer of the dam and the VNT titer of the corresponding calf (age $\leq 30$ days) of 13 dam-calf combinations sampled on the same day (Figure 3): the higher the VNT titer of the dam, the higher the VNT titer (maternal antibodies) of the calf.

\section{Conclusions}

Our field data support the assumption that natural SBV infection in adult cows results in persistence of specific antibodies for at least two years. Based on the observed decay of maternally-derived antibodies in calves, it is presumed safe to vaccinate calves against SBV at an age of approximately 6 months.

\section{Methods}

From all animals of a dairy herd in the eastern part of the Netherlands blood samples were taken five times in a 17-month period to be able to examine persistence and titers of neutralizing-antibodies against SBV over time in adult cattle and calves.

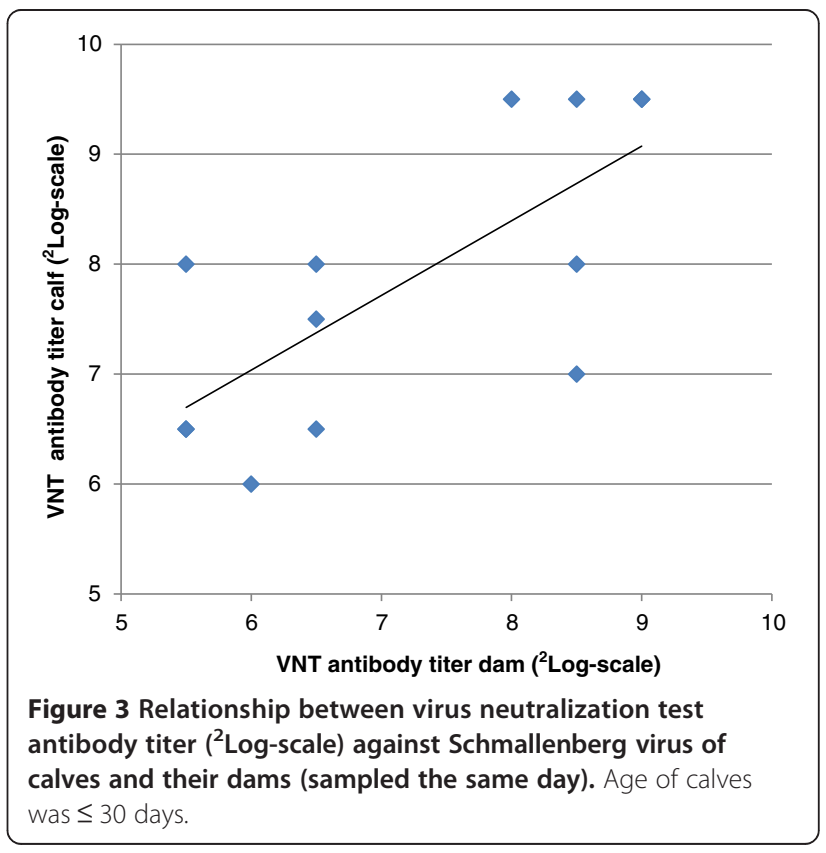


Blood samples were obtained in the context of nonexperimental clinical veterinary practices for diagnostic purposes and procedures followed were performed in accordance with the Dutch national as well as European Union animal experiment regulations.

The dairy herd consisted of 60 milking cows, 50 heifers and calves; no animals from other herds were purchased onto the farm, a few older adult cows were sold including all the male calves born. This dairy herd is the only location in the Netherlands where Culicoides monitoring was executed continuously and where SBV RNA was detected in Culicoides caught in 2011 [8] and 2012 [9]. No SBV clinical signs were observed in any cattle of the dairy herd at the end of 2011 or the beginning of 2012. All animals of the herd were blood-sampled, for the first time on 19 April 2012 after retrospective detection of SBV RNA in the Culicoides collection caught in 2011 [8].

A total of three calves were stillborn during the oneyear study period on this dairy, but all without the characteristic malformations observed after SBV infection, which was confirmed by gross pathology and all tissue samples of these calves tested SBV-negative by RT-PCR.

Blood samples were tested for antibodies using a virus neutralization test (VNT) [12], with some small modifications: dilutions tested started at 1:4 and ended at 1:512. All samples were tested in duplicate. Titers were determined using the Reed-Münch method [13] and expressed on a ${ }^{2}$ Logarithm-scale. Distribution of VNTtiters by sampling date was summarized with a box and whisker plot [14] in Figure 2: the central line in the box plot indicates the median of the data, while the edges of the box indicate the first and third quartiles (that is, the 25th and 75th percentiles); extending from the box are whiskers, the top whisker expands to the 90th percentile and the bottom whisker to the 10th percentile; beyond the whiskers are observations that are relatively far from the median.

All animals of the herd were again blood sampled on 17 September 2012 (5 months after 1st sampling), 9 December 2012 (8 months after 1st sampling), 23 April 2013 (12 months after 1st sampling) and 23 September 2013 (17 months after 1st sampling).

\section{Competing interests}

The authors declare they have no competing interests.

\section{Authors' contributions}

AE designed the study, carried out the study in the field, performed the analysis and drafted the manuscript. WP contributed to the analysis of the data. NS carried out pathology on stillborn calves of the dairy herd. NS and WP commented on the draft manuscript. All authors read and approved the final manuscript.

\section{Acknowledgements}

This study was funded by the Dutch Ministry of Economic Affairs (WOT-01001-004). We thank Eefje and Eric Meihuizen for excellent and friendly cooperation and generously providing access to their pastures and animals. We acknowledge Marjan Nijhof (Veterinary Practice AnimalCare, Putten, Netherlands) for sampling the animals at the dairy farm.

\section{Author details}

${ }^{1}$ Department of Epidemiology, Crisis organisation and Diagnostics, Central Veterinary Institute, part of Wageningen UR, PO Box 65, NL-8200AB Lelystad, Netherlands. ${ }^{2}$ Department of Infection Biology, Central Veterinary Institute, part of Wageningen UR, PO Box 65, NL-8200AB Lelystad, Netherlands.

${ }^{3}$ Department of Virology, Central Veterinary Institute, part of Wageningen UR, NL-8200AB, NL-8200AB Lelystad, Netherlands.

Received: 27 January 2014 Accepted: 23 April 2014

Published: 1 May 2014

\section{References}

1. European Food Safety Authority (EFSA): Schmallenberg Virus: Analysis of the Epidemiological Data (May 2013). Parma, Italy: Supporting Publications; 2013. Available online: http://www.efsa.europa.eu/en/publications.htm.

2. Yilmaz H, Hoffmann B, Turan N, Cizmecigil UY, Satir E, Richt JA, van der Poel WHM: Detection and partial sequencing of Schmallenberg virus in cattle and sheep in Turkey. Vector-borne and zoonotic Dis 2014, 14:223-225. doi:10.1089/vbz.2013.1451.

3. Elbers ARW, Loeffen WLA, Quak S, de Boer-Luijtze E, van der Spek AN, Bouwstra R, Maas R, Spierenburg MAH, de Kluijver EP, van Schaik G, van der Poel WHM: Seroprevalence of antibodies to Schmallenberg virus in dairy cattle, winter 2011-2012, the Netherlands. Emerg Infect Dis 2012, 18:1065-1071. doi:http://dx.doi.org/10.3201/eid1807.120323.

4. Farmers Weekly: Schmallenberg Virus Vaccine Approval Makes Good Progress. Surrey, United Kingdom: Reed Business Information Limited. February 20, 2013. http://www.fwi.co.uk/articles/20/02/2013/137748/sbv-vaccine-approvalmakes-good-progress.htm (accessed 18 May 2013).

5. Eschbaumer M, Eschweiler J, Hoffmann B: Long-term persistence of neutralising antibodies against bluetongue virus serotype 8 in naturally infected cattle. Vaccine 2012, 30:7142-7143.

6. Vitour D, Guillotin J, Sailleau C, Viarouge C, Desprat A, Wolff F, Belbis G, Durand B, Bakkali-Kassimi L, Breard E, Zientara S, Zanella G: Colostral antibody induced interference of inactivated bluetongue serotype- 8 vaccines in calves. Vet Res 2011, 42:18. doi:10.1186/1297-9716-42-18.

7. Kimman TG, Westenbrink F, Schreuder BEC, Straver PJ: Local and systemic antibody response to bovine respiratory syncytial virus infection and reinfection in calves with and without maternal antibodies. J Clin Microbiol 1987, 25:1097-1106.

8. Elbers ARW, Meiswinkel R, van Weezep E, van Kooi EA: Schmallenberg virus detected by RT-PCR in Culicoides biting midges captured during the 2011 epidemic in the Netherlands. Emerg Infect Dis 2013, 19:106-109.

9. Elbers ARW, Meiswinkel R, van Weezep E, Kooi EA, van der Poel WHM: Schmallenberg virus in Culicoides biting Midges in the Netherlands in 2012. Transbound Emerg Dis. in press; doi:10.1111/tbed.12128.

10. Tsutsui T, Yamamoto T, Hayama Y, Akiba Y, Nishiguchi A, Kobayashi S, Yamakawa M: Duration of maternally derived antibodies against Akabane virus in calves: survival analysis. J Vet Med Sci 2009, 71:913-918.

11. Grimstad PR, Williams DG, Schmitt SM: Infection of white-tailed deer (Odocoileus virginianus) in Michigan with Jamestown Canyan virus and the importance of maternal antibody in viral maintenance. J Wildl Dis 1987, 23:12-22.

12. Loeffen W, Quak S, de Boer-Luijtze E, van der Poel WHM, Bouwstra R, Maas R: Development of a virus neutralisation test to detect antibodies against Schmallenberg virus and serological results in suspect and infected herds. Acta Vet Scand 2012, 54:44.

13. Reed $L$, Muench $\mathrm{H}$ : A simple method of estimating fifty percent end points. Am J Hyg 1938, 27:493-497.

14. PROC GPLOT, SAS version 9.3. Cary, NC, USA: SAS Institute Inc; 2012 (http://www.sas.com).

doi:10.1186/1746-6148-10-103

Cite this article as: Elbers et al:: Schmallenberg virus antibody persistence in adult cattle after natural infection and decay of maternal antibodies in calves. BMC Veterinary Research 2014 10:103. 